real limitations these have. ${ }^{6}$ Even when an exacerbation has clearly been caused by a stress, removing the cause is usually too late to arrest the condition; the bolting horse requires physical methods of restraint or else has to be left to run itself out.

${ }^{1}$ Whitlock, F A, Psychophysiological Aspects of Skin Disease. London, Saunders, 1976.

${ }^{2}$ Farber, E M, and Cox, A J, eds, Psoriasis. Procezdings of the International Symposium. Stanford University 1971. Stanford, Stanford University Press, 1971.

${ }^{3}$ Farber, E M, and Cox, A J, eds, Psoriasis. Proceedings of the 2nd International Symposium. New York, Yorke Medical, 1977.

${ }^{4}$ Watson, W, et al, Archives of Dermatology, 1972, 105, 197.

${ }^{5}$ Farber, E M, and Nall, M L, Dermatologica, 1974, 148, 1.

${ }^{6}$ British Medical Fournal, 1977, 1, 988.

Ingram, J T, British Medical fournal, 1954, 2, 823.

${ }^{8}$ Savin, J A, Transactions of the St Fohn's Hospital Dermatological Society, 1970, 56, 139.

${ }^{9}$ Baughman, R, and Sobel, R, Archives of Dermatology, 1971, 103, 599.

10 Seville, R H, British fournal of Dermatology, 1977, 97, 297.

11 Seville, R H, British fournal of Dermatology, 1978, 98, 151

12 Coles, R B, Transactions of the St Fohn's Hospital Dermatological Society, 1967, 53, 82.

13 Skott, A, Mobacken, H, and Starmark, J E, British fournal of Dermatology, $1977,96,445$.

\section{Gastrointestinal bleeding in acute respiratory failure}

Acute upper gastrointestinal bleeding occurs in between $5 \%$ and $30 \%$ of critically ill patients with severe burns, ${ }^{12}$ head injuries, ${ }^{3}$ and postoperative respiratory failure. ${ }^{45}$ Recently attention has been drawn ${ }^{6}$ to the high incidence of this type of bleeding in the adult respiratory distress syndrome. The latter is an incompletely understood disorder characterised by diffuse damage to the pulmonary capillary endothelium and the alveoli leading to pulmonary oedema and arterial hypoxaemia. Though most commonly associated with severe trauma and sepsis, the syndrome is sometimes found in other conditions which cause non-cardiogenic pulmonary oedema, such as acute viral pneumonia and aspiration of gastric contents. ${ }^{78}$ In one series reported from Kansas $\mathrm{City}^{6}$ gastrointestinal haemorrhage occurred in 11 of 13 patients with the adult respiratory distress syndrome in contrast to four of 44 patients with acute exacerbations of chronic obstructive bronchitis who required assisted ventilation.

What causes the gastrointestinal haemorrhage? It may be due to reactivation of chronic peptic ulcer, ${ }^{9}$ oesophagitis related to recumbency, ${ }^{10}$ or a bleeding diathesis, ${ }^{11}$ but in most cases is caused by the stress-induced gastric erosions, ${ }^{6}$ usually in the body and fundus of the stomach, which are seen in most critically ill patients. ${ }^{3} 5$ These erosions probably result from mucosal ischaemia with disruption of the gastric mucosal barrier and increased back-diffusion of acid. ${ }^{1}$ Paralytic ileus, with reflux of duodenal contents into the stomach, may occur in any severe illness, and experimentally reflux has been shown to increase both the incidence and the severity of stress erosions. ${ }^{1}$

Some additional factors may also be relevant to the high incidence of gastrointestinal haemorrhage in the adult respiratory distress syndrome. Arterial hypoxia would potentiate any cellular hypoxia in the gastric mucosa; and the low arterial carbon dioxide tension, which often occurs in the early stages of the syndrome, may, through vasoconstriction, further impair oxygen delivery to these cells. Once ulceration is established any coagulation defects will increase the risk of haemorrhage. Thrombocytopenia-frequently present in the syndromewas a risk factor in the Kansas patients, ${ }^{6}$ including three of the four with chronic obstructive bronchitis who bled. Platelet aggregation and deposition of platelets on damaged pulmonary capillaries are probably factors in the pathogenesis of this type of respiratory distress syndrome ${ }^{7}$ and may partly explain the thrombocytopenia, though in severe acute respiratory failure (including this syndrome) platelets may be sequestrated in the liver and spleen rather than in the lungs. ${ }^{12}$ Local fibrinolysis in the gastric mucosa may promote gastric haemorrhage in both acute and chronic ulceration ${ }^{13}$ and disseminated intravascular coagulation, a recognised complication of the syndrome, may also cause bleeding. Corticosteroids are commonly used to treat the adult respiratory distress syndrome, but do not appear to increase the risk of gastrointestinal haemorrhage ${ }^{6}$ : indeed, they may reduce the incidence of stress-induced erosions in various types of shock. ${ }^{14}$

The high morbidity and mortality from haemorrhage from stress-induced gastric erosions ${ }^{4}{ }^{6}$ indicate that prophylactic treatment should be attempted. Treatment with antacids can reduce the incidence of gastrointestinal bleeding in patients with burns, ${ }^{2}$ trauma, sepsis, and acute respiratory failure. ${ }^{61516}$ Antacids seem to limit or prevent stress erosions by increasing intragastric $\mathrm{pH}$, but they need to be given often enough to maintain gastric $\mathrm{pH}$ above 5.0 if bleeding is to be prevented. ${ }^{1617}$ The $\mathrm{H}_{2}$-receptor blockers can arrest haemorrhage from acute erosions. ${ }^{18}$ In a controlled study of patients with fulminant hepatic failure intravenous infusion of cimetidine prevented haemorrhage from acute erosions by maintaining gastric $\mathrm{pH}$ above 5.0, whereas four-hourly antacid treatment, which kept gastric $\mathrm{pH}$ above 5.0 in only $35 \%$ of patients, failed to prevent haemorrhage. ${ }^{17}$ Fibrinolytic inhibitors might reduce the need for blood transfusion and operation in gastrointestinal haemorrhage from erosions, but in the adult respiratory distress syndrome fibrin deposition in alveoli is already occurring, and pulmonary thromboemboli are commonplace, ${ }^{78}$ so that further therapeutic inhibition of fibrinolysis seems unwise. The prophylactic value of propantheline bromide has not been established clinically, though in experimental stress it reduces the incidence of acute gastric mucosal lesions, blood loss, and acid secretion. ${ }^{19}$

At present, then, the simplest prophylactic approach is to give adequate doses of antacids. Cimetidine may prove equally effective; but we need a prospective trial to determine its value in patients with acute respiratory failure.

${ }^{1}$ Skillman, J J, and Silen, W, Lancet, 1972, 2, 1303.

2 McAlhany, J C, Czaja, A J, and Pruitt, B A, fournal of Trauma, 1976, 16, 645.

${ }^{3}$ Kamada, T, et al, fournal of Trauma, 1977, 17, 44

4 Skillman, J J, et al, American fournal of Surgery, 1969, 117, 523.

5 Lucas, C E, et al, Archives of Surgery, 1971, 102, 266.

${ }^{6}$ Harris, S K, Bone, R C, and Ruth, W E, Chest, 1977, 72, 301.

7 Murray, J F, American Review of Respiratory Diseases, 1977, 115, 1071.

Branthwaite, M A, in 13th Symposium on Advanced Medicine, ed M Besser, 289. Tunbridge Wells, Pitman, 1977.

9 Williams, M H, Medicine (Baltimore), 1966, 45, 317

10 Reuben, A, Dilawari, J, and Cotton, P B, Gut, 1975, 16, 410.

11 Bone, R C, Francis, P B, and Pierce, A K, American fournal of Medicine, 1976, 61, 585.

12 Schneider, R C, et al, American Review of Respiratory Diseases, 1976, 113 suppl, 135.

13 British Medical fournal, 1977, 2, 1565.

14 Jama, R H, Perlman, M H, and Matsumoto, T, American fournal of Surgery, 1975, 130, 328.

15 Wilson, W S, et al, American fournal of Surgery, 1973, 126, 133.

${ }^{16}$ Curtis, I E, et al, American fournal of Surgery, 1973, 125, 474.

17 MacDougall, B R D, Bailey, R J, and Williams, R, Lancet, 1977, 1, 617.

${ }_{18}$ MacDonald, A S, Steele, B J, and Bottomley, M G, Lancet, 1976, 1, 68.

19 Guth, P H, et al, Gastroenterology, 1975, 69, 1048. 